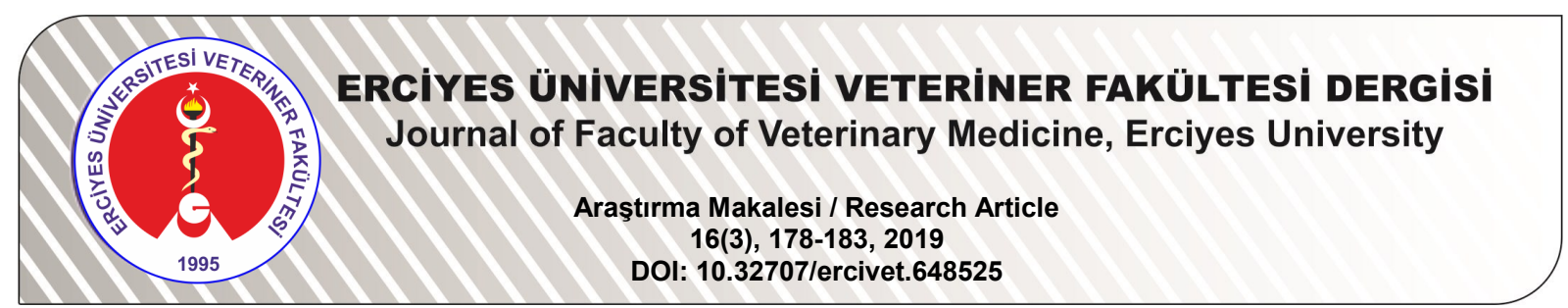

\title{
Diyarbakır Yöresindeki Çiğ Koyun Sütlerinin Mikrobiyolojik, Fiziko-Kimyasal ve Organoleptik
} Özelliklerinin Araştırılması

\author{
Mehmet Nesip ÇELIK ${ }^{1}$, Aydın VURAL ${ }^{2}$, Mehmet Emin ERKAN ${ }^{3}$ \\ ${ }^{1}$ Bingöl Adaklı İlçe Gıda Tarım ve Hayvancılık Müdürlüğü, Bingöl, TÜRKiYE \\ ${ }^{2}$ Dicle Üniversitesi Veteriner Fakültesi Besin/Gıda Hijyeni ve Teknolojisi ABD, Diyarbakır, TÜRKIYE \\ ${ }^{3}$ Şırnak Üniversitesi Rektörlügü, Mehmet Emin Acar Kampüsü, Şırnak, TÜRKIYYE
}

\begin{abstract}
*Sorumlu Yazar: Aydın VURAL; E-posta: avural@dicle.edu.tr; ORCID: 0000-0002-6232-2131
Atıf yapmak için: Çelik MN, Vural A, Erkan ME. Diyarbakır yöresindeki çiğ koyun sütlerinin mikrobiyolojik, fiziko-kimyasal ve organoleptik özelliklerinin araştırıması. Erciyes Üniv Vet Fak Derg 2019; 16(3): 178-183.

Özet: Bu çalışmada Diyarbakır İlinde 100 farklı çiftlikten toplanan koyun sütlerinin bileşimi ve kalite özellikleri ile muhtemel halk sağlığı risklerinin belirlenmesi amaçlanmıştır. Koyun sütü örneklerindeki ortalama toplam mezofilik aerob bakteri, toplam psikrofilik aerob bakteri, koliform, Escherichia coli, Staphylococcus-Micrococcus spp., laktobasil, laktik streptokok, küf-maya ile sülfit redükte eden anaerob bakteri sayıları sırası ile $7.83,6.92,4.55,3.61,4.50,6.23,7.95$, 4.27 ve $2.71 \log _{10} \mathrm{kob} / \mathrm{ml}$ olarak saptanmıştır. Analiz edilen koyun sütlerinde ortalama yağ, yağsız kuru madde, protein, laktoz ve mineral madde miktarları ile yoğunluk, donma noktası ve pH değerleri ise sırası ile $\% 7.93, \% 11.88, \% 4.96, \%$ $5.99, \% 0.77,1.035,-0.615^{\circ} \mathrm{C}$ ve $6.55^{\prime}$ tir. Koyun sütü örneklerindeki ortalama somatik hücre sayısı $5.77 \log _{10}$ hücre $/ \mathrm{ml}$; kıvam, görünüm-renk, tat ve koku puanları ise sırasıyla 5.0, 4.0, 5.0 ve 4.5 olarak tespit edilmiştir ( 5 'li skala). Diyarbakır'dan temin edilen koyun sütlerinin beslenme ve endüstriyel açıdan önemli bir potansiyel oluşturduğu, ancak hijyenik kalitelerinin düşük olduğu saptanmıştır. Koyun yetiştiricilerinin sağım hijyeni ve sütün muhafazası hakkında eğitilmesine intiyaç bulunduğu kanaatine varılmıştır.
\end{abstract}

Anahtar kelimeler: Halk sağlığı, hijyen, hücre sayısı, koyun sütü, somatik hücre sayısı

\section{The Study of the Microbiological, Physico-Chemical and Organoleptic Properties of the Raw Ewe's Milk in} Diyarbakır Province

Summary: In this study, it is aimed to determine the nutrition compounds, it's quality features and the probable risks for community health of milk samples from 100 different farms in Diyarbakir Province. The average total mesophilic aerobic bacteria, total psychrophilic aerobic bacteria, coliform, Escherichia coli, Staphylococcus-Micrococcus spp., lactobacillus, lactic streptococci, mould-yeast and sulfide reducing anaerobe bacteria in ewe's milk were determined as $7.83,6.92,4.55,3.61,4.50,6.23,7.95,4.27$ and $2.71 \log _{10} \mathrm{cfu} / \mathrm{ml}$, respectively. The average values of fat, non-fat dry matters, protein, lactose, quantity of mineral matters and density, freezing point and $\mathrm{pH}$ value are $7.93 \% .11 .88 \%, 4.96 \%, 5.99 \%, 0.77 \%, 1.035,-0.615^{\circ} \mathrm{C}$ and 6.55 in order. The average number of somatic cells in ewe's milk samples was recorded as $5.77 \log _{10} \mathrm{cell} / \mathrm{ml}$; consistence, color\&appearance, taste and smell scores are 5.0 , 4.0, 5.0 and 4.5 in order (five point scala). It was concluded that the ewe's milk produced in Diyarbakır Province constitutes an important potential in terms of industry but the hygienic quality is low. It was agreed that the sheep breeders need to be trained on milking hygiene and storage conditions.

Key words: Ewe's milk, hygiene, public health, somatic cell count

\section{Giriş}

Koyun sütünde ortalama yağ $\% 7.4$, protein $\% 5.5$, mineral madde $\% 1.0$ ve kurumadde miktarı $\% 19.3$ düzeyindedir (17). Kazein oranının yüksek olması peynir ve yoğurt üretiminde; yağ oranının yüksek oluşu ise tereyağı üretiminde koyun sütünün tercih edilmesini sağlamaktadır $(17,28)$. Koyun sütünün doğal asitliği diğer türlere nazaran daha yüksek olup sonradan oluşan asitlik yavaş gelişmektedir (17). İnek

\begin{tabular}{ll}
\hline Geliş Tarihi/Submission Date & $: 11.12 .2018$ \\
Kabul Tarihi/Accepted Date & $: 28.02 .2019$
\end{tabular}

"Bu çalışma "2. Uluslararası Hayvansal Gıdalar Kongresi'nde" poster olarak sunulmuştur.

Bu çalışma Veteriner-16.001 kodlu Tez Projesinden özetlenmiştir. ve keçi sütüne göre daha beyazımsı renkte (26) olan koyun sütünün kendine özgü olan biraz ağır tadı ve kokusu bulunmaktadır. İçme sütü olarak kullanımı sınırlıdır (28). Koyun sütleri $B_{1}, B_{2}$, niasin, biotin ve $C$ vitaminleri yönünden inek sütlerine oranla daha zengindir (26).

$\mathrm{Bu}$ çalışmada, özellikle kırsal alanlarda büyük bir ekonomik değer olan koyunculuğun en önemli çıktılarından olan koyun sütünün kalite özellikleri incelenmiştir. Diyarbakır'da koyunculuk yapan 100 farklı işletmenin sütlerinin mikrobiyolojik özellikleri ve somatik hücre sayıları (SHS) incelenerek sütlerin hijyenik durumu ve muhtemel sağlık risklerinin araştırılması amaçlanmıştır. Fiziko-kimyasal özelliklerin incelenmesiyle sütün bileşimi, besleyici değeri ve endüstride 
kullanılma açısından kalite durumunun belirlenmesi hedeflenmiştir. Organoleptik özelliklerin incelenmesi ise tüketicinin koyun sütüne yaklaşımını ortaya koymak amacıyla gerçekleştirilmiştir.

\section{Gereç ve Yöntem}

Bu çalışmada analiz edilen çiğ koyun sütleri Diyarbakır'da koyunculuğun yüksek oranda yapıldığı Karacadağ yöresindeki işletmelerden temin edilmiştir. Materyal olarak kullanılan 100 (yüz) adet çiğ koyun sütü farklı koyunculuk işletmelerinin akşam ve sabah sütlerini birlikte içeren süt tanklarından veya süt muhafa- leştirilmiştir. Mikrobiyolojik analizler için aseptik koşullarda alınan $1 \mathrm{ml}$ koyun sütü içerisinde $9 \mathrm{ml}$ steril fizyolojik tuzlu su (\%0.85 $\mathrm{NaCl})$ bulunan steril deney tüplerine eklenerek 1:10'luk ardışık dilüsyonları yapılmıştır. Mikrobiyolojik analizlerde kullanılan besiyerleri ve inkübasyon koşulları Tablo 1'de gösterilmiştir. Analizi yapılacak mikroorganizmalar için uygun besiyerlerine yayma ve dökme plak yöntemi ile ekimler gerçekleştirilmiştir. İnkübasyon sonunda tabloda belirtilen üretici firmalar tarafından besiyerleri için belirtiIen tipik koloniler sayılmıştır (Tablo 1).

Koyun sütlerinin yağ, yağsız kuru madde (YKM), pro-

Tablo 1. Mikrobiyolojik analizlerde kullanılan besiyerleri ve inkübasyon koşulları

\begin{tabular}{lll}
\hline Mikroorganizma & Besiyeri & Inkübasyon koşulları \\
\hline TMAB & PCA (Merck 1.05463) & $37^{\circ} \mathrm{C}^{\prime}$ de $24-48$ saat \\
TPAB & PCA (Merck 1.05463) & $4^{\circ} \mathrm{C}^{\prime}$ de 7 gün \\
Koliform & VRB (Merck 1.01406) & $37^{\circ} \mathrm{C}^{\prime}$ de 24 saat \\
E. coli sayımı & TBX Medium (Oxoid CM945) & $30^{\circ} \mathrm{C}$ 'de 4 saat ve \\
& & $44^{\circ} \mathrm{C}$ 'de 18 saat \\
Staphylococcus-Micrococcus spp. & BPA (Merck 1.05406) & $37^{\circ} \mathrm{C}$ 'de 24 saat \\
Laktobasil & MRSA (Merck 1.010660) & $37^{\circ} \mathrm{C}$ 'de 48-72 saat \\
Laktik streptokok & M17 Agar (Merck 1.15108) & $37^{\circ} \mathrm{C}$ 'de 24 saat \\
Küf-maya & PDA (Merck 1.010130) & $22^{\circ}-25^{\circ} \mathrm{C}$ 'de 4-5 gün \\
SRAB & SPSA (Merck 1.10235) & $37^{\circ} \mathrm{C}^{\prime}$ de 24-48 \\
\hline
\end{tabular}

za kaplarından alınmıştır. Her bir işletmeden tek bir örnek alınmıştır. Sütler en az 300 ml olacak şekilde steril numune alma poşetlerinde ve soğuk muhafaza altında $\left(+4^{\circ} \mathrm{C}\right)$ laboratuvara getirilerek geciktirilmeksizin analizleri yapılmıştır. Koyun sütü örneklerinde mikrobiyolojik analizler, fiziko-kimyasal analizler, so- tein, laktoz ve mineral madde miktarı ile donma noktası ölçümleri Funke Gerber Lactostar 3510 süt analiz cihazı (Almanya), pH değerlerinin ölçümü İnolab WTW730 laboratuar tipi pH metre ve SHS Milkana Somatic Scan cihazı ile üretici firmanın ölçüm prosedürüne uygun olarak ölçülmüştür.

Tablo 2. Koyun sütü örneklerinde saptanan minimum, maksimum ve ortalama mikroorganizma sayısı $\left(\log _{10} \mathrm{kob} / \mathrm{ml}\right)$ ile kontaminasyon düzeyi (n: 100)

\begin{tabular}{lcccc}
\hline Mikroorganizma türü & $\begin{array}{c}\text { Pozitif örnek } \\
\text { oranı (yüzde) }\end{array}$ & Min & $\begin{array}{c}\text { Mikroorganizma sayısı } \\
\text { Maks }\end{array}$ & $\begin{array}{c}\text { Ortalama } \\
\text { Sapma }\end{array}$ \\
\hline TMAB & & & 10.58 & $7.83 \pm 1.39$ \\
TPAB & 100 & 3.30 & 9.74 & $6.92 \pm 1.70$ \\
Koliform & 75 & 1.00 & 6.72 & $4.55 \pm 1.33$ \\
E. coli & 91 & 1.78 & 6.91 & $3.61 \pm 1.18$ \\
Staphylococcus-Micrococcus & 75 & 1.00 & 7.08 & $4.50 \pm 1.36$ \\
spp. & 80 & 2.00 & 10.00 & $6.23 \pm 1.21$ \\
Laktobasil & 67 & 1.48 & 10.00 & $7.95 \pm 1.24$ \\
Laktik streptokok & 71 & 4.48 & 7.32 & $4.27 \pm 1.67$ \\
Küf-maya & 56 & 2.00 & 5.30 & $2.71 \pm 0.70$ \\
SRAB & 20 & 2.00 & & \\
\hline
\end{tabular}

matik hücre sayısı (SHS) ve organoleptik analizler gerçekleştirilmiştir.

Koyun sütü örneklerinde toplam mezofilik aerob bakteri (TMAB), toplam psikrofilik aerob bakteri (TPAB), koliform bakteri, E. coli, Staphylococcus-Micrococcus spp., laktobasil, laktik streptokok, küf-maya ile sülfit redükte eden anaerob bakteri (SRAB) sayılarının saptanması amacıyla mikrobiyolojik analizler gerçek-
Koyun sütlerinin organoleptik özellikleri kıvam, görünüm-renk, tat ve koku yönünden incelenmiştir. Eğitimli yedi panelistten oluşturulan panellerde 5'li puanlama sistemi ile değerlendirme yapılmıştır. Sütler çiğ olarak kıvam, görünüm-renk ve koku yönünden; kaynatıldıktan (2 dk) sonra ise tat yönünden incelenmiştir. 
Tablo 3. Koyun sütü örneklerinin fiziko-kimyasal özellikleri

\begin{tabular}{|c|c|c|c|}
\hline Özellik türü & & bileşen & likleri \\
\hline & Min. & Maks. & Ortalama \pm Std Sapma \\
\hline Yağ (\%) & 4.42 & 15.93 & $7.93 \pm 2.01$ \\
\hline Yağsız kuru madde (\%) & 9.49 & 16.29 & $11.88 \pm 0.99$ \\
\hline Protein (\%) & 3.66 & 7.11 & $4.96 \pm 0.90$ \\
\hline Laktoz (\%) & 3.47 & 8.92 & $5.99 \pm 1.24$ \\
\hline Mineral madde (\%) & 0.51 & 1.17 & $0.77 \pm 0.15$ \\
\hline Yoğunluk & 1.026 & 1.077 & $1.035 \pm 0.007$ \\
\hline Donma noktası $\left({ }^{\circ} \mathrm{C}\right)$ & -0.521 & -0.763 & $-0.615 \pm 0.040$ \\
\hline $\mathrm{pH}$ & 6.30 & 6.90 & $6.55 \pm 0.12$ \\
\hline
\end{tabular}

Tablo 4. Koyun sütü örneklerinde SHS sonuçları $\left(\log _{10}\right.$ hücre $\left./ \mathrm{ml}\right)$ ve SHS dağılımı

\begin{tabular}{|c|c|c|c|c|c|c|c|}
\hline \multirow{2}{*}{$\begin{array}{l}\text { Pozitif } \\
\text { örnek } \\
\text { (yüzdesi) }\end{array}$} & \multicolumn{3}{|c|}{ SHS sonuçları $\left(\log _{10}\right.$ hücre/ml) } & \multicolumn{4}{|c|}{ SHS dağılımı (örnek sayısı ve yüzdesi) } \\
\hline & Min. & Maks. & $\begin{array}{l}\text { Ortalama } \\
\text { Std Sapma }\end{array}$ & $90-250 \times 10^{3}$ & $250-500 \times 10^{3}$ & $500-1000 \times 10^{3}$ & $>1000 \times 10^{3}$ \\
\hline $38(\% 38)$ & 4.97 & 7.18 & $5.77 \pm 0.37$ & $29(\% 29)$ & $7(\% 7)$ & $1(\% 1)$ & $1(\% 1)$ \\
\hline
\end{tabular}

Tablo 5. Koyun sütü örneklerinde organoleptik puanlama sonuçları (n:100)

\begin{tabular}{lcccc}
\hline & Kıvam & Görünüm-Renk & Tat & Koku \\
\hline Çok iyi-5 puan & 51 & 49 & 53 & 50 \\
İyi-4 puan & 32 & 42 & 38 & 35 \\
Az kusurlu-3 puan & 17 & 9 & 9 & 15 \\
Kusurlu-2 puan & - & - & - & - \\
Tüketilemez-1 puan & - & - & - & - \\
\%25'lik dilim & 4 & 4 & 4 & 4 \\
\%75'lik dilim & 5 & 5 & 5 & 5 \\
Medyan & 5 & 4 & 5 & 4.5 \\
\hline
\end{tabular}

\section{Bulgular}

Bu çalışmada koyun sütü örneklerinde mikrobiyolojik, fiziko-kimyasal ve organoleptik kalite parametreleri ile SHS incelenmiştir. Analiz edilen koyun sütü örneklerinin mikrobiyolojik analiz sonuçları Tablo 2'de; fizikokimyasal analiz sonuçları Tablo 3'te, somatik hücre sayıları ve dağılımı Tablo 4'te ve organoleptik analiz bulguları ise Tablo 5'te verilmiştir. Organoleptik analizlerin yorumlanmasında 5 puan çok iyi, 4 puan iyi, 3 puan az kusurlu, 2 puan kusurlu ve 1 puan tüketilmez (kabul edilemez) olarak kullanılmıştır.

\section{Tartışma ve Sonuç}

Koyun sütlerindeki TMAB sayısı Merlin Junior ve ark. (16) tarafından $16 \times 10^{6} \mathrm{kob} / \mathrm{ml}$ olarak bulunmuştur. Sevi ve ark. (22) TMAB sayısının laktasyon yılına göre farklılık gösterebildiğini, 1., 2. ve 3. laktasyonda sırasıyla $5.29,4.99$ ve $4.83 \log _{10} \mathrm{kob} / \mathrm{ml}$ düzeylerinde olduğunu saptamıştır. Talevski ve ark. (24) ise Makedonya'da üç farklı süt toplama bölgesindeki ortalama TMAB sayısını $1.5 \times 10^{7} \mathrm{kob} / \mathrm{ml}$ olarak bildirmiştir. Koyun sütlerindeki TPAB sayısı $5.8 \times 10^{6} \mathrm{kob} / \mathrm{ml}$ (16) ile 4.83-517 $\log _{10} \mathrm{kob} / \mathrm{ml}(22)$ düzeylerinde tespit edilmiştir. Sevi ve ark. (22) 1., 2. ve 3. laktasyonda sırasıyla koyun sütlerinde koliform sayısını 3.81, 3.57 ve
$3.40 \log _{10} \mathrm{kob} / \mathrm{ml}$; fekal koliform bakteri sayısını ise $1.28,1.12$ ve $0.94 \log _{10} \mathrm{kob} / \mathrm{ml}$ olarak saptamıştır. Talevski ve ark. (24) süt toplama bölgelerindeki koliform sayısını $7.2 \times 10^{5} \mathrm{kob} / \mathrm{ml}$ olarak bildirmiştir. Brezilya'da yapılan bir çalışmada koyun sütlerinde koliform ve $E$. coli kontaminasyon oranları ise sırası ile $\% 100$ ve \%45 olarak bulunmuştur (16). Sanjuan ve ark. (21) koyun sütlerindeki laktobasil sayısını $3.68 \log _{10} \mathrm{kob} /$ $\mathrm{ml}$; Kondyli ve ark. (13) ise boutsiko ırkı koyunlarda 5.04-5.87 $\log _{10} \mathrm{kob} / \mathrm{ml}$, karamaniko ırkı koyunlarda 5.06-55 $\log _{10} \mathrm{kob} / \mathrm{ml}$ olarak tespit etmiştir. Koyun sütlerinde laktokok sayısı ise $5.26 \log _{10} \mathrm{kob} / \mathrm{ml}$ olarak bulunmuştur (21). Koyun sütlerinde küf-maya sayısı boutsiko ırkı koyunlarda 2.59-3.09 $\log _{10} \mathrm{kob} / \mathrm{ml}$, karamaniko ırkı koyunlarda 2.57-3.18 $\log _{10} \mathrm{kob} / \mathrm{ml}$ olarak bildirilmiştir. Merlin Junior ve ark. (16) inceledikleri koyun sütlerinin tamamında $S$. aureus kontaminasyonu bildirmiştir. Bu çalışmada saptanan bakteri sayıları Talevski ve ark.'nın (24) bulduğu koliform sayısı ile Merlin Junior ve ark. (16) bildirdikleri S. aureus kontaminasyon düzeyleri haricinde diğer araştırma sonuçlarından daha yüksektir. Araştırma materyalimizi tank sütlerinin oluşturması bulduğumuz yüksek kontaminasyon düzeylerinin nedeni olarak görülmektedir. Tank sütleri farklı hayvanların sütlerinden oluştuğundan memeden elde edilen sütlerden daha fazla bakteri yükü içerdikleri düşünülmektedir. Sağım hijyeni; 
sağımda kullanılan alet, ekipman ve/veya sütün konulduğu kapların hijyenik durumu, memenin dış yüzeyinin kirlilik durumu, sağım sonrası ile sütün muhafazaya alınması arasında geçen süre, sütlerin taşınma koşulları, sütlerin muhafaza edildiği sıcaklık dereceleri, süte koruyucu bir maddenin konulup konulmaması, sağılan hayvanların sağlık durumu, hayvanların mastitisli (özellikle subklinik ve kronik mastitislerde) olup olmadıkları, sağım zamanı, mevsim ve lokasyon bakteri yükünün fazla olması araştırma sonuçları arasındaki farklıkların nedeni olarak düşünülmektedir.

Koyun sütündeki yağ oranını Ocak ve ark. (18) \%4, Kondyli ve ark. (13) \%6.76-7.71, Bencini ve Purvis (4) $\% 8.48$ olarak bildirilmiştir. Bizim sonuçlarımız Simos ve ark. (23) tarafından bildirilen ortalama değer (\% 7.85 ) ile uyumludur. Bu çalışmada analiz edilen sütler koyunların laktasyon sonu dönemlerine aittir. Karaca ve ark. (11) süt veriminin laktasyon döneminin sonlarında azalmasının yüksek yağ oranına neden olduğunu bildirmiştir. Yılmaz ve ark. (30) akkaraman ırkı koyunlarda YKM miktarını \%9.8, Ocak ve ark. (18) norduz ırkı koyunlarda YKM miktarını \%10.6, Akça ve Bakır (1) ise zom ırkı koyunlarda YKM miktarını \% 12.4 olarak bildirmiştir. Bizim sonuçlarımız Akça ve Bakır'ın (1) bildirdiği değerlerden düşük iken diğer iki araştırmacının sonuçlarından daha yüksektir. Çelik ve Özdemir'in (7) Morkaraman ırkı koyunlarda bildirdiği \%11.41 ile Karaca ve ark.'In (11) Karakaş koyunlarında bulduğu \%11.66 değerler ise sonuçlarımız ile benzerlik göstermektedir. Koyun sütündeki protein oranını Casoli ve ark. (6) \%4.7, Bencini ve Purvis (4) ise $\% 4.8$ olarak bulmuştur. Bizim çalışmamızdaki ortalama protein oranı bu çalışmalardan daha yüksek iken diğer araştırmacıların bulduğu değerlerden ise (\%5.2-7.4) daha düşüktür $(9,18,29,30)$. Koyun sütlerinde protein miktarının nispeten düşük bulunması meraya dayalı beslenme yapılması ve meraların zayıf olması ile ilişkilendirilmektedir. Koyun sütlerinde bulunan laktoz miktarları \%4.28 (12) ile \%6.8 (1) arasında değişmektedir. Bizim çalışmamızda bulunan ortalama laktoz değerleri de bu aralıkta (\%5.99) olmasına rağmen nispeten birçok çalışmadan daha yüksektir $(3,7,9,29,30)$. Laktoz miktarının yüksek olması memenin sekretuar epitel hücrelerinin sentez kapasitesinin iyi çalıştığını ve subklinik mastitis olmadığının göstergesi olarak yorumlanmaktadır. Koyun sütlerinde yapılan çeşitli araştırmalarda çoğunlukla kül miktarı ölçümleri yapılmıştır ve kül miktarının $\% 0.81$ ile $\% 1$ arasında bulunduğu görülmektedir $(9,11,25,27,30)$. Koyun sütü bileşimi açısından yüksek besleyici değere sahip ve kaliteli süt ürünleri üretimine uygun bir süttür. Ancak yapılan birçok araştırmada koyun sütlerinin bileşimlerinde farklılıklar görülmektedir $(1,4,6,9,18,30)$. Bu farklılıkların koyun ırkı, coğrafya, beslenme, mevsim, laktasyon dönemi, sağım zamanı ve analiz yöntemlerinden kaynaklanması muhtemeldir.

$\mathrm{Bu}$ çalışmada incelenen koyun sütlerinde ortalama yoğunluk 1.035 olarak bulunmuştur. Bu sonuçlar Akça ve Bakır'ın (1) Zom ırkı koyunları için bulduğu ortalama değerlerden (1.039) daha düşüktür. Sütün bileşenleri sütün yoğunluğunu etkilemektedir. Yüksek yağ oranı yoğunluğun düşük olmasına neden olurken, yağsız kuru madde oranının artması yoğunluğu da artırmaktadır. Analiz edilen koyun sütlerindeki ortalama donma noktası $-0.615{ }^{\circ} \mathrm{C}$ olarak bulunmuştur. Koyun sütündeki donma noktası Konar (12) tarafından yapılan bir çalışmada $-0.56{ }^{\circ} \mathrm{C}$ olarak bildirilmiştir. Sütün su dışındaki bileşenleri arttıkça donma noktası düşmektedir. Laktasyon döneminin sonundaki sütlerde kuru madde miktarının artmasına bağlı olarak da donma noktası düşmektedir. Analiz edilen koyun sütü örneklerinde ortalama $\mathrm{pH}$ değeri 6.55 olarak saptanmıştır. Kondyli ve ark. (13) Boutsiko ve Karamaniko ırkı koyun sütlerinde bahar ve yaz aylarında $\mathrm{pH}$ değerlerini 6.75-6.82 arasında bulmuştur. Sütün tazeliği, sütteki mikroorganizma miktarı veya memedeki mastitis durumu sütün $\mathrm{pH}$ değeri üzerine etkilidir. Düşük $\mathrm{pH}$ değeri sütün kötü hijyenik kalitede olduğunu veya uygun olmayan muhafaza koşullarında tutulduğunu göstermektedir.

Memede subklinik mastitis olduğunu saptamak için sınır SHS birçok çalışmada farklılıklar göstermektedir. Araştırmacılar SHS için sınır değer olarak 250.000 hücre/ml $(2,8)$ ile 500.000 hücre $/ \mathrm{ml}$ arasında değerler bildirmiştir (5). Berthelot ve ark. (5) subklinik mastitis olduğunu söylemek için memedeki SHS'nin 1.000.000 hücre/ml üzerinde olması gerektiğini bildirilmiştir. Antunac ve ark. (2) travnik ırkı koyunlarda laktasyonun başında SHS'nin en yüksek değerde olduğunu $\left(1.57 \times 10^{6} / \mathrm{ml}\right)$; laktasyon sonunda ise en düşük SHS'nin $\left(0.26 \times 10^{6} / \mathrm{ml}\right)$ ve en düşük günlük süt veriminin tespit edildiğini bildirmiştir. Leitner ve ark. (15) koyun sütlerinde yaptıkları çalışmalarında enfekte olmayan memelerdeki SHS'yi fossomatik cihazı ile ortalama $5.15 \log _{10}$ ve enfekte memelerde ise ortalama 6.32 log olarak tespit etmişlerdir. Koyunlarda tank sütündeki SHS ile ilgili çalışmalar ise daha azdır. Araştırmalar koyun tank sütlerinde ortalama SHS sayısının 400.000-500.000 ile 1.000.000-1.200.000 hücre/ml arasında değiştiğini göstermektedir (14). Bu çalışmada saptanan ortalama SHS $5.77 \log _{10}$ hücre/ $\mathrm{ml}$ düzeyindedir. Bizim bulduğumuz değerler Lagriffoul ve ark. (14) ile Leitner ve ark.'nın (15) bildirdiği değerlerle uyumlu iken, Paape ve ark. (19) tarafından bildirilen sonuçlardan ise daha yüksektir. Bu çalışmada SHS sonuçları koyunlarda subklinik mastitis için bildirilen değerlerin altında iken TMAB, TPAB, koliform, E. coli ve Staphylococcus-Micrococcus spp. gibi bakteri sayıları nispeten yüksek düzeydedir. Somatik hücre sayısı sınır değerin altında olmasına rağmen sütte bakteri varlığının yüksekliğinin muhtemel enfeksiyonun ilk aşamalarından veya daha önce meydana gelen enfeksiyonlardan kaynaklanmış olabileceği bildirilmiştir (10). Bu durum sağım sırasında veya sonrasındaki kontaminasyonlardan da kaynak- 
lanmış olabilir. Diğer taraftan bizim çalışmamızda süt örnekleri akşam ve sabah sütlerinin bulunduğu tanklardan alınmıştır. Somatik hücre sayısı yüksek olsa bile süt içerisinde dilüsyona uğramış ve dolayısıyla düşük sayıda saptanmış olması muhtemeldir. Mastitis problemi çok yoğun ve SHS çok yüksek düzeyde ise tank sütleri bizim için önemli bir uyarıcı olabilir. Koyunlarda SHS gerçek anlamda mastitis ile ilişkilendirmek için her hayvandan ve her bir meme lobundan ölçüm yapılması daha doğrudur. Kullanılan analiz yöntemi, kullanılan cihazların koyunlar için ölçüme ayarlanması, kalibrasyon durumu, süte koruyucu katılıp katılmaması, sütün muhafaza sıcaklığı ve analiz sıcaklığı da SHS değerlerini etkilemektedir (20).

$\mathrm{Bu}$ çalışmada analiz edilen koyun sütü örneklerinin organoleptik özelliklerinin medyan değerleri kıvam, görünüm-renk, tat ve koku için sırasıyla $5,4,5$ ve 4.5 olarak bulunmuştur. Bu sonuçlara göre kıvam ve tat açısından koyun sütlerinin panelistler tarafından çok iyi olarak, görünüm-renk açısından ise iyi olarak değerlendirildiği görülmektedir. Koku açısından sonuçlar ise iyi ve çok iyi aralığındadır. İncelenen koyun sütlerinin kıvam, görünüm-renk, tat ve koku için sırasıyla $\% 83, \% 91, \% 91$ ve $\% 85$ 'i kabul edilebilir değerlerin üzerinde puan ile değerlendirilmiştir. Düşük hijyenik kalite, ağıl koşullarının kötü olması, uygun olmayan şartlarda muhafaza, panelistlerin tüketim alışkanlıkları ve eğitim durumları da organoleptik sonuçlar üzerine etki etmiş olabilir.

Koyun sütü, inek sütünden sonra en fazla tüketilen süt olarak özel damak tadına sahip tüketici kitlesi tarafından özellikle tercih edilmektedir. Yüksek kuru madde içeriğine sahip koyun sütünün besin değeri ve süt ürünlerine işlenme potansiyeli de yüksektir. Koyun sütünden genellikle yüksek randımana sahip, lezzeti ve tekstürü beğenilen yoğurt ve peynir gibi ürünler üretilmektedir. Koyun sütü ile ilgili gerek mikrobiyolojik ve gerekse SHS yönünden mevzuatta düzenlemeler yapılmasına intiyaç olduğu sonucuna varılmıştır. Bu çalışmada çiğ koyun sütlerinin hijyenik kalitesinin oldukça düşük olduğu görülmüştür. Yüksek mikroorganizma yüküne sahip bu sütlerin halk sağlığı açısından risk teşkil edebileceği düşünülmektedir. Meme, altlık, ağıl, sağım ve ekipman hijyeni ile sütlerin muhafaza koşullarında eksiklikler olduğu kanaatine varılmıştır. Koyun sütünün besleyici değeri ve bileşimi konusunda toplumun bilgilendirilmesi, koyun sütünün ekonomik bir getiri olan koyun sütüne yönelik sektör yapılanmasının artırılması, hijyenik sağım yöntemleri ile sütün muhafazası konularında yetiştiricilerin eğitilmesi ve sağım sonrası tüm aşamalarda soğuk zincirin korunması gerektiği sonucuna varılmıştır.

\section{Teşekkür}

Veteriner-16.001 kodlu proje ile bu yüksek lisans tez çalışmasının yapılmasındaki katkılarından dolayı Dicle Üniversitesi Bilimsel Araştırma Projeleri Biri- mi'ne (DÜBAP) teşekkür ederiz.

\section{Kaynaklar}

1. Akça N, Bakır G. Karacadağ Zom koyununun süt bileşimi. Dicle Üniv Vet Fak Derg 2017; 10(1): 1923.

2. Antunac N, Mioc B, Pavic V, Havranek JI, Samarzija D. The effect of stage of lactation on milk quantity and number of somatic cells in sheep milk. Milchwissenschaft 2002; 57(6): 310-1.

3. Barłowska J, Szwajkowska M, Litwinczuk Z, Krol J. Nutritional value and technological suitability of milk from various animal species used for dairy production. Compr Rev Food Sci F 2011; 10(6): 291-9.

4. Bencini R, Purvis IW. The yield and composition of milk from Merino sheep. Proc Aust Soc Anim Prod 1990; 18: 144-7.

5. Berthelot X, Lagriffoul G, Concordet D, Barillet F, Bergonier D. Physiological and pathological thresholds of somatic cell counts in ewe milk. Small Ruminant Res 2006; 62(1-2): 27-31.

6. Casoli C, Duranti E, Morbidini L, Panella F, Vizioli V. Quantitative and compositional variations of massese sheep milk by parity and stage of lactation. Small Ruminant Res 1989; 2(1): 47-62.

7. Çelik Ş, Özdemir S. Morkaraman ırkı koyun sütlerinin bazı kimyasal ve fizikokimyasal parametrelerinin laktasyon boyunca değişimi. Atatürk Üniv Ziraat Fak Derg 2003; 34(3): 263-8.

8. De la Cruz M, Serrano E, Montoro V, Marco J, Romeo M, Baselga R, Albizu I, Amorena B. Etiology and prevalence of subclinical mastitis in the Manchega sheep at mid-late lactation. Small Ruminant Res 1994; 14(2): 175-80.

9. Doğan Ş, Aytekin İ, Boztepe S. Anadolu Merinosu koyunlarında meme tipleri ile meme özellikleri, süt verimi ve bileşenleri arasındaki ilişkiler. Namık Kemal Üniv Tekirdağ Ziraat Fak Derg 2013; 10(2): 58-69.

10. Fthenakis GC. Somatic cell counts in milk of Welsh-Mountain, Dorset-Horn and Chios ewes throughout lactation. Small Ruminant Res 1996; 20(2): 155-62.

11. Karaca O, Akyüz N, Andiç S, Altın T. Karakaş koyunlarının süt verim özellikleri. Turk $\mathrm{J}$ Vet Anim Sci 2003; 27(3): 589-94.

12. Konar A. İnek, keçi ve koyun sütlerinin donma noktası depresyonu ve süte su katılarak yapılan hilenin saptanması. Gıda 1982; 7(2): 56-61. 
13. Kondyli E, Svarnas C, Samelis J, Katsiari MC. Chemical composition and microbiological quality of ewe and goat milk of native Greek breeds. Small Ruminant Res 2012; 103(2-3): 194-9.

14. Lagriffoul G, Barillet F, Rupp R, Berthelot X, Bergonier $D$. Somatic cell counts in dairy sheep milk. Great Lakes Dairy Sheep Symposium. 38-56. 2006; Wisconsin-USA.

15. Leitner G, Chaffer M, Caraso Y, Ezra E, Kababea D, Winkler M, Glickman A, Saran A. Udder Infection and milk somatic cell count, NAGase activity and milk composition-fat, protein and lactose-in Israeli-Assaf and Awassi sheep. Small Ruminant Res 2003; 49(2): 157-64.

16. Merlin Junior IA, Santos JS, Costa LG, Costa RG, Ludovico A, Rego FC, Santana EH. Sheep milk: physical-chemical characteristics and microbiological quality. Arch Latinoam Nutr 2015; 65(3): 193-8.

17. Metin M. Süt Teknolojisi Sütün Bileşimi ve İşlenmesi. 4. Baskı, İzmir: Ege Üniversitesi Basımevi 2001; ss. 1-483.

18. Ocak E, Bingöl M, Gökdal Ö. Van yöresinde yetiştirilen Nordus koyunlarının süt bileşimi ve süt verim özellikleri. YYÜ Tar Bil Derg 2009; 19(2): 859.

19. Paape MJ, Bernard P, Contreras A, Marco CJ, Capuco AV. Milk somatic cells and lactation in small ruminants. J Dairy Sci 2001; 84: 237-44.

20. Raynal-Ljutovac K, Pirisi A, De Crémoux R, Gonzalo C. Somatic Cells of goat and sheep milk: analytical, sanitary, productive and technological aspects. Small Ruminant Res 2007; 168(1-2): 126 -44 .

21. Sanjuan S, Rúa J, García-Armesto MR. Microbial flora of technological interest in raw ovine milk during $6^{\circ} \mathrm{C}$ storage. Int J Dairy Technol 2003; 56 (3): 143-8.

22. Sevi A, Taibi L, Albenzio M, Muscio A, Annicchiarico $G$. Effect of parity on milk yield, composition, somatic cell count, renneting parameters and bacteria counts of Comisana ewes. Small Ruminant Res 2000; 37(1-2): 99-07.

23. Simos EN, Nikolaou EM, Zoiopoulos PE. Yield, composition and certain physicochemical characteristics of milk of the Epirus Mountain sheep breed. Small Ruminant Res 1996; 20(1): 67-74.

24. Talevski G, Čobanova-Vasilevska R, Srbinovska S, Sireta Z. Quality of the sheep milk as a raw material in dairy industry of Macedonia. Biotechnol Anim Husb 2009; 25 (5-6): 971-77.
25. Tekin ME, Kadak R, Gürkan M, Nazlı M, Kurtoğlu V. Merinos, Akkaraman ve İvesi koyunlarının bazı etçi Irklar ile melezlenmesinden elde edilen f1 koyunların süt verimi ve süt kompozisyonu. Hayvancılık Araş Derg 1994; 4(1): 13-8.

26. Üçüncü M. Süt Mamulleri Teknolojisi. Birinci Baskı. İmir: Meta Basım Matbaacılık Hizmetleri; 2013, s. 5-6.

27. Verdalet GI, Pedraza VP, Peralta LM, Perezgrovas $\mathrm{R}$, Silva HE. Estudio Sobrela Caracterización Fisicoquímica de la Leche de Ovejas Criolla de Chiapas. Part II. Teller Internacional Sobre la Calidad de la Leche (Study on Phsyicochemical Milk Characterization of Criolla de Chiapas Ewes. Part II. Internacional Workshop on Milk Quality), 4-8, 1993; Mexico DF.

28. Yerlikaya $O$, Karagözlü $C$. Koyun sütünün beslenmedeki önemi ve teknolojik özellikleri. Süt Dünyası Dergisi 2008; 14(3): 58-61.

29. Yılmaz O, Çak B, Bolacalı M. Effects of lactation stage, age, birth type and body weight on chemical composotion of Red Karaman sheep milk Kafkas Univ Vet Fak Derg 2011; 17(3): 383-386.

30. Yılmaz O, Denk H, Nursoy H. Milk yield characteristics of Norduz sheep. YYÜ Vet Fak Derg 2004; 15(1-2): 27-31. 